\title{
Graffiti of Prison: A Diversity of Writings
}

\author{
Philippe Hameau* \\ Professor in Archaeology and Anthropology, France
}

Submission: November 02, 2018; Published: November 14, 2018

*Corresponding author: Philippe Hameau, Professor in Archaeology and Anthropology, France

\section{Write to Exist}

The practice of writing can establish an answer to a traumatic experience. It is a liberator of tensions: a "traumatography" according to Tellier [1]. It allows to engage a process of resilience by its reactive character.However, if we imagine that the writing of an intimate diary or any autobiographical narrative can calm its author, we think that simple graffiti play less the same role: doubtlessly because they are concise, reduced to some words or motives. We also think that an autobiographical narrative infers and longtime reflection while graffiti are compulsiveness and revelations of the present moment.Nevertheless, it is essentially graffiti which we observe on the walls of the Prison.They are markings which the legislator considers " as useful psychological diversions " [2]: he understands the necessity, but he disapproves the shape, maybe less for their infringement on the integrity of the prison furniture than by their provoking voyeurism. The prison graffiti assaults because it is a display of the intimacy and of the feelings of its authors in terms which care few corrections. It bothers because it exposes the psychological and social wounds of his authors.At the same time, it requests the reaction of the other individuals who see them and decipher them.

However, we cannot consider these graphic acts in a context of confinement as being of the same global nature.In the diversity of the courses of their authors, before and during the incarceration, answers a big variability of messages. To the multiplicity of the situations and the characters corresponds a plurality of expectations in reaction to the wall inscriptions. The laminarity of the prison space does not lead to a simple isolation of the individuals at the side of the society. It imposes to the individual new rules within a heterogeneous group, on behalf of the administration as much as of that of the prisoners. As in many of the " totalitarian institutions " Goffman [3], the prison is an environment where the hierarchical organization is important, where the group is micro-stratified and where the administration tries to make impervious between them the various categories of individuals.

Nevertheless, at the same time as takes place this ceaseless process of otherness, the individuals are forced to the crowding as much as to the differentiation[4]. Graffiti show these multiple contradictions. They are conceivable, quite at the same time, as a conditioning in the rules of the incarceration and as an uncontrollable need to express an identity denied by the Administration. They also reveal uncountable individual trajectories.

\section{Scatter Messages}

Few prisoners have written on walls before being imprisoned and nevertheless graffiti abound from the "incomers' cells": mostly names and first names matched of a date and of the reference of a city.The membership in a community space is there particularly persistent.It is also claimed in the cells of the Courts and the police stations, in contrast with its slightest representation in the other cells except for the district of the minors. The incomers' cells are the spaces where the texts are the longest and most detailed. Sometimes, a dialogue begins between a newcomer who makes act of contrition or who rebels against an informer and a recidivist who indicates him the obligation that he will have to submit himself to new rules. It is a way of making his new condition understand to the newcomer.

In the ordinary cells, graffiti are realized, globally and in ascending order, at the side of the bed, at the level of the desk, on the back wall with the unique window. They are visible of everybody. It may be necessary to see a lesser repression against these graphic acts there, today.Even if, often, four individuals live in the same cell, graffiti are in the intimate places. Names of the men and their wife or girlfriend, judgments and discounts represent the main part of the corpus. Invectives against the penal and judicial system are numerous in a stereotypical form. The more the authority is distant, the more it is castigated. Graffiti are rarely managed against the staff of the establishment, except for tensions inside this one.

This strategy is a way of respecting a "peaceful coexistence" says a guard. Graffiti also stigmatize "balances", that is individuals suspected of collusion with the leading of the prison. Any misdemeanor of an individual is interpreted as a will of nuisance against the other prisoners. In these ordinary cells, the most patent graffiti are the most revealing feelings of the group. It is often about maxims on the life, love, death, god and 
of course confinement. Maxims are repeated in every arrival of a new prisoner: "the prison is hard, but the release is sure", for example. They are consensual expressions the duplication of which is necessary to become integrated into one's new universe.

Common areas as court, showers and rooms where take place workshops establish spaces of graffiti.However, the graphic practice is not here compulsory because it is replaced by the oral communication.

Contrary to other spaces, the disciplinary district represents the place of the extreme, personalized and signed invectives. The name of the cities of origin of the prisoners is expressed there for a better identification of their authors. The disciplinary ward shows itself as a "grateful passage" as certain guards say. It is the space which assures a status to the prisoner and will save him from the humiliations of his co-cellular. We find in it very numerous mentions to a role reversal: there the prisoners say themselves to be the real bosses of the prison establishment.

Paradoxically, the disciplinary ward can be felt as a place of resourcing. It is a "rest room" a prisoner writes, "before going out back in the jungle".

In prison, we attend a clear sexual division of the scriptural tasks. Men express themselves gladly on walls whereas women prefer the writing of intimate newspapers and often venture on the poetry.On the other hand, the disciplinary district tends to erase any differentiation of the genres.The disciplinary ward of establishments for women are covered with graffiti which have the same violence as in the disciplinary district of the men.In their cells, women thus prefer scrupulously to keep up to date exercise books.Questioned, certain of them explain this choice by a will to leave behind them no track of their passage. This track would oblige them to return, as if the graffiti possessed a charm which pushes them to the repeat offense.

\section{Question of the Time}

Some of the themes which seemed inherent to the prison graffiti[5] become scarce nowadays.To the old drawings of sublimated women is substituted the displaying of pictures of the models of fashion. The old graffiti of means of transport, doubtlessly suggesting an impossible travel, are replaced nowadays by posters of racing cars and trucks.

The time is not any more registered on walls with the same frequency because the ownership of a diary is authorized.We still observe it of course, but often reduced to both terms of the entrance and the release cells of the establishment.The time is sometimes calculated in days under the shape of alignments of six short lines crossed by a long oblique line: the line for Sundays which is the longest and saddest day of the week.The discount of days often begins when the accused becomes held, as if the expectation of the judgment was a suspended and not quantifiable time.The time would be measurable, in a way, only for a punishment the term of which is known. It is essentially counted when the duration does not exceed three or four months or when the prisoner is assigned to the disciplinary district, a situation which can be only temporary.

The duration of the confinement can also be mentioned in its entirety, by several days or month, accompanied with the identity of the prisoner. Present and future are only counted, the past is omitted.

Finally, the cloak room which indicates the outgoings' cells mentions generally the date of the release. Because of the last formalities to be achieved, this date is not necessarily the one that the prisoners hope. A prisoner writes "locked but free" to indicate that he finished his punishment but that he must stay in prison a few days furthermore.

\section{Watch, See and Look}

Questioned, the guards are often amazed that there are [still] graffiti in cells. They tell not to read them, but they know the contents.They see them without looking at them.In fact, graffiti become prohibited since they question the authority of the Administration. Their author is brought to appear in front of the disciplinary Council if his graffiti are managed against the team of the guards.These ones are laxer when the invective remains non-specialized: against the Justice, against the Country, etc. However, they pay attention to the intensity of the invective to warn a revolt or a suicide.Thus, the graffiti is designed as a barometer to estimate the ill-being of the prisoners.It is consulted if it seems to reflect the feeling of the group.It is ignored, if it is considered strictly personal.

Does a graffiti try to draw the attention and to provoke the event? The indifference of the guards punishes much more the prisoner because the so waited retort does not arrive, because the time strictly given by the Administration does not change. In an ordinary cell is written: "my words cannot saw bars ". Doubtlessly, but these words contain an intrinsic strength which allows the prisoners to negotiate their place, in the middle of their peers and within the prison hierarchy. Graffiti also allow them to cut off this binding environment.

\section{References}

1. Tellier A (1998) Expériences traumatiques et écritures, Anthropos, Economic (edn), Paris, France pp. 108.

2. Larguier J (1998) Criminologie et science pénitentiaire, Série Mémentos Dalloz, Dalloz Paris (edn), France pp. 249.

3. Goffman E (1968) Asiles : études sur la condition sociale des malades mentaux. Paris, France pp. 247.

4. Le Caisne L (2000) Prison, une ethnologue en centrale, Odile Jacob (edn), Paris, France pp. 394.

5. Hameau PH, Morel M, Truchi S (2006) Les graffiti de l'ombre, des archives de Brignoles aux graffiti de sa prison, Hyères, Du Lau (edn), pp. 255. 
(C) This work is licensed under Creative (C) DOI: 10.19080/GJAA.2018.07.555709
Your next submission with Juniper Publishers will reach you the below assets

- Quality Editorial service

- Swift Peer Review

- Reprints availability

- E-prints Service

- Manuscript Podcast for convenient understanding

- Global attainment for your research

- Manuscript accessibility in different formats ( Pdf, E-pub, Full Text, Audio)

- Unceasing customer service

Track the below URL for one-step submission https://juniperpublishers.com/online-submission.php 